\title{
PENGARUH KARAKTERISTIK PEKERJAAN DAN STRES KERJA TERHADAP KEINGINAN PINDAH TEMPAT KERJA PADA PEKERJA PROYEK KONSTRUKSI
}

\author{
Fajar Susilowati $^{1, \unrhd),}$ Tri Widya Swastika ${ }^{2)}$ \\ ${ }^{1)}$ Teknik Sipil Universitas Tidar Magelang \\ ${ }^{2)}$ Teknik Sipil Politeknik Negeri Jakarta \\ email:1'fajar.susilowati@untidar.ac.id, ${ }^{2}$ triwidya.swastika@sipil.pnj.ac.id
}

\begin{abstract}
Human resources are seen as an essential asset in a company because man is a dynamic resource and always needed in every process of production of goods and services. Therefore, this research was performed to analyze the influence of Jobs' Characteristics and Work Stress on Turnover Intention. This research uses Quantitative Data by Questionnaire Method. The result of data processing shows that Work Stress has a stronger influence on Turnover Intention than Jobs Characteristics. Both of these variables impact amounted to 0.65 of the employee turnover intentions. It can calculate that determination coefficient $42.3 \%$, which means that the variable Jobs Characteristic and Work Stress have contributed amounted to $42.3 \%$ of the employee turnover intentions, while other variables determine $57.7 \%$. The indicator most influence on turnover intention in construction employees was the differences in value between the company and its employees.
\end{abstract}

Key words: Jobs' Characteristic, Work Stress, Turnover Intention

\begin{abstract}
ABSTRAK
Sumber daya manusia dipandang sebagai asset yang penting di suatu perusahaan, karena manusia merupakan sumber daya yang dinamis dan selalu dibutuhkan dalam tiap proses produksi barang dan jasa. Oleh karena itu, penelitian dilakukan untuk menganalisa pengaruh Karakteristik Pekerjaan dan Stress Kerja terhadap Keinginan Pindah Tempat Kerja (Turnover Intention). Penelitian ini menggunakan data kuantitatif dengan metode kuisioner. Hasil pengolahan data menunjukkan bahwa Stres Kerja memiliki pengaruh lebih kuat dibandingkan Karakteristik Pekerjaan terhadap Turnover Intention. Kedua variabel tersebut berpengaruh sebesar 0.65 terhadap Turnover Intention, maka dapat dihitung koefisien determinasinya yaitu 42.3\%, artinya bahwa Variabel Karakteristik Pekerjaan dan Stres Kerja memberikan konstribusi sebesar 42.3\% terhadap Turnover Intention pada pekerja proyek konstruksi, sedangkan $57.7 \%$ ditentukan oleh variabel lain. Indikator yang paling berpengaruh terhadap Turnover Intention pada pekerja proyek konstruksi adalah adanya perbedaan antara nilainilai perusahaan dan karyawan.
\end{abstract}

Katakunci : Karakteristik Pekerjaan, Stres Kerja, Turnover Intention

\section{PENDAHULUAN}

Sumber daya manusia dipandang sebagai asset perusahaan yang penting, karena manusia merupakan sumber daya yang dinamis dan selalu dibutuhkan dalam tiap proses produksi barang dan jasa. Berdasarkan beberapa data yang diperoleh dilapangan menunjukkan bahwa tingkat turnover karyawan pada beberapa perusahaan cukup tinggi. Hal ini disebabkan oleh beberapa faktor, dimana faktor-faktor tersebut menimbulkan keinginan berpindah (turnover intention) pada karyawan [1]. Saat ini permasalahan tingginya tingkat turnover intention telah menjadi masalah serius bagi banyak perusahaan. Dampak negatif yang dirasakan akibat terjadinya turnover pada perusahaan yaitu pada kualitas dan kemampuan untuk menggantikan karyawan yang keluar dari perusahaan, sehingga butuh waktu 
serta biaya baru dalam merekrut karyawan baru [2].

Dari sudut pandang perusahaan, pergantian karyawan dapat mengakibatkan penambahan biaya yang tidak sedikit menyangkut biaya perekrutan, pelatihan dan biaya yang telah dikeluarkan untuk mengatasi pergantian karyawan dan berbagai biaya tidak langsung seperti kehilangan karyawan yang telah mengerti tentang berbagai pekerjaan dalam perusahaan tersebut [3].

Dari beberapa penelitian terdahulu yang telah dilakukan banyak dibahas tentang karakteristik pekerjaan dan stres kerja Salah satunya dapat dijelaskan bahwa karakteristik individu yang baik diakibatkan kemampuan yang positif dan nyata dalam meningkatkan kepuasan kerja yang ditunjukkan melalui tingkat kompetensi yang tinggi. Hal ini mejadi salah satu penentu keberhasilan [3][4][5][6][7].

Pekerja merupakan asset perusahaan dan pelaku utama yang menjalankan roda bisnis suatu perusahaan. Namun demikian masih belum ada yang mengkaitkan kedua hal tersebut dengan adanya turnover pada suatu perusahaan khususnya pada bidang konstruksi. Oleh karena itu, maka perlu dilakukan penelitian lebih lanjut mengenai pengaruh karteristik pekerjaan dan stres kerja terhadap turnover intention pekerja pada proyek konstruksi untuk memperoleh informasi yang sebenarnya guna peningkatan kinerja karyawan sebagai modal utama perusahaan dalam melaksanakan roda bisnis perusahaan [3].

Berdasarkan uraian di atas maka perlu dilakukan penelitian mengenai Stres Kerja dan Karakteristik Perusahaan untuk mengurangi adanya tingkat Turnover Intention yang ada saat ini. Dengan demikian penelitian ini akan membahas lebih jauh tentang Stres Kerja dan Karakteristik Pekerjaan pengaruhnya terhadap Turnover
Intention yang ada pada Pekerja Proyek Konstruksi.

\section{METODE PENELITIAN}

Penelitian ini menggunakan pendekatan kuantitatif, berjenis deskriptif dan asosiatif. Responden dalam penelitian ini berjumlah 31 pekerja yang diambil secara acak berdasarkan lama kerja pada bidang kerjanya masing-masing. Lama kerja yang menjadi persyaratan sebagai responden dalam penelitian ini adalah minimal 3 tahun kerja di bidang konstruksi.

Dalam upaya mendapatkan hasil penelitian yang valid, peneliti mengolah, mengelompokkan dan menguraikan variabel-variabel penelitian berdasarkan hasil studi literatur yang telah dilakukan menjadi suatu konstruk hubungan antara karteristik pekerjaan, stres kerja, dan turnover intention yang dijelaskan dalam Tabel 1

Masing-masing indikator yang dijelaskan pada Tabel 1 selanjutnya diolah menjadi beberapa pertanyaan supaya memudahkan responden dalam memahami setiap indikator yang dijadikan tolak ukur dalam upaya untuk mengetahui hubungan antara karteristik pekerjaan, stres kerja, dan turnover intention tiap pekerja konstruksi yang menjadi responden dalam penelitian ini.

Sumber data diperoleh dari hasil kuisioner yang dibagikan kepada pekerja konstruksi yang menjadi responden dalam penelitian ini melalui kuesioner online yang dibagikan kepada mereka. Data yang sudah diperoleh selanjutnya diolah menggunakan alat bantu software statistik dan dianalisis lebih lanjut menggunakan analisis regresi dan korelasi.

\section{HASIL dan PEMBAHASAN}

Pengujian regresi linier berganda digunakan untuk menguji pengaruh variabel-variabel bebas terhadap 
variabel terikat, baik secara parsial dengan menggunakan uji t, maupun secara bersama-sama dengan menggunakan uji F. Berikut hasil dari pengujian linier berganda dengan alat bantu software.

Dari Tabel 2 diperoleh persamaan regresi $\mathrm{Y}=17.749-0.318 \mathrm{X}_{1}+0.710 \mathrm{X}_{2}$. Persamaan tersebut dapat diartikan bahwa:

a. Konstanta 17.749 menunjukkan bahwa jika seluruh variabel bebas diasumsikan nilai 0 , maka variabel Y adalah sebesar 17.749. Ini berarti walaupun tanpa dipengaruhi variabel $\mathrm{X}$, maka variabel $\mathrm{Y}$ memiliki nilai tetap sebesar 17.749.

b. Nilai koefisien regresi X1 sebesar 0.318 memiliki makna bahwa jika variabel X1 mengalami perubahan satu satuan atau di naikan $100 \%$ dan variabel bebas lainnya diasumsikan bernilai 0, maka akan menurunkan nilai variabel Y sebesar 0.318 .

c. Nilai koefisien regresi X2 sebesar 0.710 memiliki makna bahwa jika variabel X2 mengalami perubahan satu satuan atau di naikan $100 \%$ dan variabel bebas lainnya diasumsikan bernilai 0, maka akan meningkatkan nilai variabel Y sebesar 0.710.

Selanjutnya pengolahan data dilakukan lebih detil terhadap masing-masing indikator pada variabel Stres Kerja (X2) yang memiliki pengaruh kuat terhadap turnover intention (Y) untuk memperoleh informasi mengenai indikator apakah yang terkait dengan Variabel X2 yang paling berpengaruh terhadap Variabel $\mathrm{Y}$ pada pekerja konstruksi. Berikut adalah hasil dari pengujian terhadap pengeruh masingmasing indikator pada Variabel X2 terhadap Variabel Y dengan alat bantu software.

Dari nilai koefisien regresi pada kolom (B) pada Tabel 3, dapat diketahui bahwa indikator Variabel X2 yang paling berpengaruh terhadap Variabel Y adalah indikator X2.9 atau terkait dengan masalah perbedaan antara nilai-nilai perusahaan dan karyawan. Hal ini dapat dijelaskan bahwa jika terdapat perbedaan nilai-nilai kehidupan yang ada di perusahaan dengan nilai-nilai kehidupan yang dibawa oleh karyawan, maka besar kemungkinan karyawan tersebut akan merasa tidak nyaman sehingga muncul keinginan untuk keluar dari tempat kerjanya dan berpindah ke perusahaan lain atau mencari pekerjaan lainnya.

Pengujian korelasi berganda yaitu untuk mengetahui hubungan antara variabel Karakteristik Pekerjaan (X1) dan Stres Kerja (X2) terhadap variabel Turnover Intention (Y) yang dilakukan bersamaan. Hasil pengujian korelasi berganda didapatkan hasil seperti ditabelkan dalam Tabel 4.

Berdasarkan Tabel 4 tersebut diperoleh angka $\mathrm{R}$ sebesar 0.650. Hal ini menunjukan bahwa terjadi hubungan yang kuat antara Karakteristik Pekerjaan (X1) dan Stres Kerja (X2) terhadap variabel Turnover Intention (Y) karena berada pada rentang 0.601-0.800.

Dari Nilai koefisien korelasi (R) sebesar 0.650 yang menunjukkan kekuatan hubungan antara variabel $\mathrm{X}$ (Karakteristik Pekerjaan dan Stres Kerja) terhadap variabel Y (Turnover Intention), diperoleh nilai koefisien determinasi (R-Square) sebesar 0.423 . Hal ini menunjukan bahwa variabel $\mathrm{X}$ memberikan konstribusi pengaruh sebesar $42.3 \%$ terhadap Variabel Y, sementara sisanya sebesar $57.7 \%$ dipengaruhi oleh faktor lain.

Berdasarkan analisis data di atas, dapat dijelaskan bahwa Turnover Intention atau keinginan untuk keluar dari tempat kerja muncul sangat dipengaruhi oleh stress kerja di tempat kerja. Hal ini sangat rentan terjadi diperusahaan konstruksi mengingat salah satu sifat konstruksi yang tidak menetap dan berpindah tempat jika proyek sudah selesai sehingga menuntut adanya adaptasi yang cukup tinggi terhadap 
berbagai situasi. Namun demikian perubahan tersebut bukanlah merupakan indikator utama yang menyebabkan terjadinya stress kerja. Adanya perbedaan antara nilai-nilai perusahaan dan karyawan merupakan salah satu indikator utama yang menyebabkan terjadinya stress kerja dan menimbulkan terjadinya Turnover Intention pada industri jasa konstruksi.

\section{KESIMPULAN}

Formula hubungan antara karteristik pekerjaan, stres kerja, dan turnover intention pada pekerja konstruksi adalah $\mathrm{Y}=17.749-0.318 \mathrm{X}_{1}+0.710 \mathrm{X}_{2}$. Pengaruh karteristik pekerjaan dan stres kerja terhadap turnover intention pada pekerja konstruksi diperolah nilai koefisien korelasi (R) sebesar 0.650 yang menunjukkan kekuatan hubungan antara variabel X (Karakteristik Pekerjaan dan Stres Kerja) terhadap variabel Y (Turnover Intention), diperoleh nilai koefisien determinasi (R-Square) sebesar 0.423. Hal ini menunjukan bahwa variabel $\mathrm{X}$ memberikan konstribusi pengaruh sebesar 42.3\% terhadap Variabel Y, sementara sisanya sebesar $57.7 \%$ dipengaruhi oleh faktor lain. Indikator yang paling berpengaruh terhadap turnover intention pada pekerja konstruksi adalah adanya perbedaan antara nilai-nilai perusahaan dan karyawan.

\section{UCAPAN TERIMAKASIH}

Penelitian ini dibiayai dengan Dana DIPA Politeknik Negeri Jakarta, Penelitian Riset Grand Tahun Anggaran $2015 . \quad$ Nomor kontrak: 307/PL3.B/SPK/2016 tanggal 1 Juli 2016.

\section{DAFTAR PUSTAKA}

[1] A. Malik, "Pengaruh Budaya Organisasi dan Loyalitas Kerja Dengan Intensi Turnover Pada Karyawan PT. Cipaganti Heavy Equipment Samarinda," eJournal Psikol., 2014.

[2] A. S. Wahyuni, Y. Zaika, and R. Anwar, "Analisis Faktor-Faktor Yang Mempengaruhi Turnover Intention (Keinginan Berpindah ) Karyawan Pada Perusahaan Jasa Konstruksi,” J. Rekayasa Sipil, 2014.

[3] Y. Lubis, "Pengaruh Karakteristik Individu, Karakteristik Pekerjaan, Iklim Organisasi terhadap Kepuasan dan Kinerja Karyawan,” $J$. Trikonomika, 2014.

[4] A. Astianto, "Pengaruh Stres Kerja Dan Beban Kerja Terhadap Kinerja Karyawan PDAM," J. Ilmu Ris. Manaj., 2014.

[5] Chadek Novi Charisma Dewi, M. S. . Dr.I Wayan Bagia, and M. . Gede Putu Agus Jana Susila, S.E., "Pengaruh Stres Kerja dan Kepuasan Kerja Terhadap Kinerja Karyawan Pada Bagian Tenaga Penjualan Ud Surya Raditya Negara,” J. Jur. Manaj., 2014.

[6] S. Nazenin and P. Palupiningdyah, "Peran Stres Kerja dan Kepuasan Kerja untuk Mengurangi Turnover Intention,” J. Din. Manaj., 2014.

[7] T. Kardilla, H. Sjahruddin, and Heslina, "Dampak Karakteristik Pekerjaan dan Individu Pada Kepuasan Kerja Karyawan," ELibrary STIE YPBUP Bongaya, 2016. 
Tabel 1 Konstruk hubungan antara karteristik pekerjaan, stres kerja, dan turnover intention

\begin{tabular}{|c|c|c|c|}
\hline Variabel & Variabel & & Indikator \\
\hline \multirow{15}{*}{$\begin{array}{c}\text { Variabel } \\
\text { Bebas } \\
\text { X }\end{array}$} & \multirow{5}{*}{$\begin{array}{l}\text { Karakteristik } \\
\text { Pekerjaan } \\
\text { (X1) }\end{array}$} & $\mathrm{X} 1.1$ & Keragaman Ketrampilan \\
\hline & & $\mathrm{X} 1.2$ & Identitas tugas \\
\hline & & $\mathrm{X} 1.3$ & Signifikasi tugas \\
\hline & & $\mathrm{X} 1.4$ & Otonomi \\
\hline & & $\mathrm{X} 1.5$ & Umpan Balik \\
\hline & \multirow{10}{*}{$\begin{array}{l}\text { Stres Kerja } \\
\text { (X2) }\end{array}$} & $\mathrm{X} 2.1$ & Beban kerja yang berlebihan \\
\hline & & $\mathrm{X} 2.2$ & Tekanan atau desakan waktu \\
\hline & & $\mathrm{X} 2.3$ & Kualitas supervisi yang jelek \\
\hline & & $\mathrm{X} 2.4$ & Iklim politis yang tidak aman \\
\hline & & $\mathrm{X} 2.5$ & Umpan balik tentang pelaksanaan kerja yang tidak memadai \\
\hline & & $\mathrm{X} 2.6$ & Peranan Ganda \\
\hline & & $\mathrm{X} 2.7$ & Frustasi \\
\hline & & $\mathrm{X} 2.8$ & Konflik antar pribadi dan antar kelompok \\
\hline & & $\mathrm{X} 2.9$ & Perbedaan antara nilai-nilai perusahaan dan karyawan \\
\hline & & $\mathrm{X} 2.10$ & Berbagai bentuk perusahaan. \\
\hline \multirow{10}{*}{$\begin{array}{c}\text { Variabel } \\
\text { Terikat } \\
\text { Y }\end{array}$} & \multirow{10}{*}{$\begin{array}{l}\text { Turnover } \\
\text { Intention } \\
\quad(\mathrm{Y} 1)\end{array}$} & Y1.1 & Gaji/ upah \\
\hline & & Y1.2 & Desain pekerjaan \\
\hline & & Y1.3 & Pelatihan dan pengembangan \\
\hline & & Y1.4 & Perkembangan karir \\
\hline & & Y1.5 & Komitmen \\
\hline & & Y1.6 & Kurangnya kekompakan dalam kelompok/organisasi \\
\hline & & Y1.7 & Ketidakpuasan dan bermasalah dengan atasan atau pengawas \\
\hline & & Y1.8 & Rekrutmen \\
\hline & & Y1.9 & Seleksi dan promosi \\
\hline & & Y1.10 & Jarak geografis dari tempat kerja \\
\hline
\end{tabular}

Tabel 2 Hasil Pengujian Koefisien Regresi Linier Berganda

\begin{tabular}{|c|c|c|c|c|c|c|}
\hline & \multirow[t]{2}{*}{ Model } & \multicolumn{2}{|c|}{ Unstandardized Coefficients } & \multirow{2}{*}{$\begin{array}{c}\begin{array}{c}\text { Standardized } \\
\text { Coefficients }\end{array} \\
\text { Beta } \\
\end{array}$} & \multirow[t]{2}{*}{$\mathbf{t}$} & \multirow[t]{2}{*}{ Sig. } \\
\hline & & B & Std. Error & & & \\
\hline \multirow[t]{3}{*}{1} & (Constant) & 17.749 & 8.827 & & 2.011 & .054 \\
\hline & $\mathrm{X} 1$ & -.318 & .195 & -.235 & -1.630 & .114 \\
\hline & $\mathrm{X} 2$ & .710 & .163 & .630 & 4.364 & .000 \\
\hline
\end{tabular}

a. Dependent Variable: $\mathrm{Y}$

Sumber: Hasil olahan data dengan menggunakan alat bantu software 
Fajar Susilowati dan Tri Widya Swastika, Pengaruh Karakteristik Pekerjaan...

Tabel 3 Hasil Pengujian Koefisien Regresi terhadap masing-masing Indikator X2

\begin{tabular}{|c|c|c|c|c|c|c|}
\hline & \multirow[b]{2}{*}{ Model } & \multicolumn{2}{|c|}{ Unstandardized Coefficients } & \multirow{2}{*}{$\begin{array}{c}\begin{array}{c}\text { Standardized } \\
\text { Coefficients }\end{array} \\
\text { Beta } \\
\end{array}$} & \multirow[b]{2}{*}{$\mathbf{t}$} & \multirow[b]{2}{*}{ Sig. } \\
\hline & & $\mathbf{B}$ & Std. Error & & & \\
\hline \multirow[t]{11}{*}{1} & (Constant) & 8.768 & 5.380 & & 1.630 & .119 \\
\hline & $\mathrm{X} 2.1$ & -.962 & 1.658 & -.124 & -.580 & .568 \\
\hline & $\mathrm{X} 2.2$ & .386 & 1.266 & .060 & .305 & .763 \\
\hline & X2.3 & 1.234 & 1.188 & .164 & 1.038 & .312 \\
\hline & $\mathrm{X} 2.4$ & -.760 & .819 & -.135 & -.928 & .365 \\
\hline & $\mathrm{X} 2.5$ & 2.516 & .836 & .465 & 3.008 & .007 \\
\hline & X2.6 & .102 & .951 & .019 & .108 & .915 \\
\hline & $\mathrm{X} 2.7$ & -.117 & 1.369 & -.018 & -.085 & .933 \\
\hline & $\mathrm{X} 2.8$ & .523 & 1.206 & .093 & .433 & .669 \\
\hline & X2.9 & 2.543 & 1.140 & .435 & 2.230 & .037 \\
\hline & X2.10 & 1.257 & .969 & .198 & 1.298 & 209 \\
\hline
\end{tabular}

a. Dependent Variable: Turnover_Intention (Sumber: Hasil olahan data dengan menggunakan alat bantu software)

Tabel 4 Hasil Pengujian Korelasi Berganda

\begin{tabular}{|l|r|r|r|r|}
\hline Model & \multicolumn{1}{|c|}{$\mathbf{R}$} & R Square & Adjusted R Square & \multicolumn{1}{c|}{ Std. Error of the Estimate } \\
\hline 1 & $.650^{\mathrm{a}}$ & .423 & .382 & 4.95172 \\
\hline
\end{tabular}

